\title{
REEVALUASI PEMBIAYAAN PERUSAHAAN MELALUI MODAL VENTURA DI INDONESIA
}

\author{
Sihabudin \\ Fakultas Hukum Universitas Brawijaya \\ Jl. MT. Haryono 169 Malang \\ sihab@ub.ac.id
}

\begin{abstract}
This paper aims to discuss the development of venture capital reevaluation in Indonesia that provides an opportunity for businesses to develop the corporation through financing. This paper uses normative juridical research. The results of the analysis is that the regulation and legal policy which can provide adequate legal protection is needed to support the corporation neither the corporation founded by the State or by private parties. Capital is needed in the establishment and operation of an enterprise, including through venture capital. Therefore, the existence of venture capital should be supported by the government as a regulator and facilitator and community businesses which can grow better so that not only large companies but also small firms and medium can be helped by the growth of venture capital. On the other hand, since the inclusion of funds to the venture capital system is high risk for investors, then early investors must be careful in order to save funds or capital is entered into the corporation's business partners.
\end{abstract}

Key words: venture capital, corporation, contract

\begin{abstract}
Abstrak
Tulisan ini bertujuan untuk membahas mengenai reevaluasi Pengembangan modal ventura di indonesia memberikan kesempatan bagi pelaku bisnis untuk mengembangkan perusahaannya melalui pembiayaan.Tulisan ini menggunakan penelitian yuridis normatif. Hasil dari analisis dalam tulisan ini adalah bahwa Pengaturan dan kebijakan hukum yang dapat memberikan perlindungan hukum yang memadai diperlukan untuk mendukung kegiatan perusahaan baik perusahaan yang didirikan oleh Negara maupun oleh pihak swasta . Dalam pendirian dan operasional sebuah perusahaan dibutuhkan modal termasuk melalui modal ventura. Oleh karena itu keberadaan modal ventura harus didukung oleh pemerintah sebagai regulator dan fasilitator serta masyarakat pelaku bisnis agar modal ventura dapat berkembang lebih baik sehingga bukan hanya perusahaan besar, namun juga perusahaaan kecil dan menengah dapat terbantu oleh pertumbuhan modal ventura. Di lain pihak berhubung penyertaan dana dengan sistem modal ventura ini mengandung risiko tinggi bagi pemodal, maka dari awal pemodal (venture capitalist) harus berhati-hati guna menyelamatkan dana/modal yang dimasukkan ke dalam perusahaan mitra bisnisnya.
\end{abstract}

Kata kunci: modal ventura, perusahaan, kontrak 


\section{Latar Belakang}

Keberadaan peraturan perundangundangan sebagai ketentuan hukum yang mengatur tata kehidupan semua aspek kehidupan sangatlah pentingtermasuk hubungan hukum di bidang kegiatan ekonomi. ${ }^{1}$ Salah satu ketentuan hukum yang mengatur kegiatan ekonomi adalah ketentuan yang mengatur lembaga pembiayaan modal ventura sebagai salah satu lembaga pembiayaan bagi perusahaan kecil dan menengah, yang merupakan lembaga baru sebagai perkembangan lembaga ekonomi keuangan bukan bank. ${ }^{2}$ Di Indonesia modal ventura ini diharapkan juga berkembang, namun arahnya diharapkan dari awal untuk memberdayakan perusahaan kecil dan menengah, yang seringkali mengalami kesulitan permodalan.

Perkembangan ekonomi Indonesia di setiap tahap atau periode mempunyai karakteristik yang berbeda.Kegiatan di bidang ekonomi di Indonesia selama 30 tahun setelah tahun 1967 telah mengalami perkembangan dan perubahan banyak, tetapi karena kegiatan itu telah meninggalkan segala asas hukum, asas berbisnis yang baik dan asas keadilan, maka terjadilah krisis ekonomi yang kita alami sejak tahun 1997. Oleh karena itu "reformasi politik dan reformasi hukum sangatlah penting untuk keluar dari krisis ekonomi". ${ }^{3}$
Di masa yang lalu peraturan dan proses hukum sangat diabaikan, sementara pertimbangan ekonomi, khususnya untuk memperoleh keuntungan yang sebesar-besarnya lebih diutamakan.Paket Kebijaksanaan Oktober 1988 (PAKTO 88), yang meliberalisasi sektor perbankan dengan kemudahan pendirian bank-bank baru atau kantor-kantor cabang bank mengakibatkan bank-bank menyebar di berbagai penjuru negara. ${ }^{4}$ Hal ini dapat dimanfaatkan oleh kalangan usaha lebih meluas untuk memperoleh modal usaha, tetapi perusahaan kecil tetap sulit untuk memperoleh permodalan dari bank tersebut, disebabkan tidak memenuhi persyaratan bankable.

Persoalannya adalah justru terjadi ketimpangan antara pelaku ekonomi yang besar dan mendapat dukungan penguasa dengan pelaku ekonomi kecil yang tidak memperoleh dukungan tersebut, bahkan semakin lama semakin tidak dapat memenuhi persyaratan ekonomi maupun politis sebagai akibat bermunculannya beberapa bank yang hanya dapat dimanfaatkan oleh kalangan pengusaha besar atau pengusaha yang sudah mapan dan mampu memenuhi persyaratanpersyaratan perbankan (bankable). Sedangkan pengusaha kecil tetap tidak dapat memanfaatkan lembaga perbankan yang ada. ${ }^{5}$

1 Satjipto Rahardjo, Ilmu Hukum, (Jakarta: Balai Pustaka, 1979), hlm. 36.

2 Lihat Keputusan Presiden No. 61 tahun 1988, tentang Lembaga Pembiayaan.

3 Bandingkan Sunarjati Hartono, Politik Hukum Menuju Satu Sistem Hukum Nasional, (Bandung: Alumni, 1991), hlm. 35.

4 Sjahrir, Persoalan Ekonomi Indonesia: Moneter. Perkreditan dan Neraca Pembayara, (Jakarta: Pustaka Sinar Harapan, 1995), hlm. 146.

5 Ibid. 
Akibat dari kesempatan yang tidak merata dalam hal memperoleh modal ini, timbul ketidakadilan dan ketidakmerataan serta kesenjangan pertumbuhan dunia usaha. ${ }^{6}$

Berdasarkan uraian tersebut keberadaan dan peranan lembaga pembiayaan yang berupa modal ventura di Indonesia ini menjadi penting untuk dikaji, sebab merupakan lembaga baru yang mulai berkembang, yang tentunya mempunyai pengaruh terhadap perkembangan dunia usaha dan lembaga serta pranata hukumnya. Sayangnya lembaga ini tidak dibarengi dengan pembentukan pranata hukum yang mengatur operasional hubungan hukum antara perusahaan modal ventura dengan perusahaan yang dibiayai.

Metode yang digunakan pada penelitian ini berdasarkan sifatnya merupakan penelitian yuridis empiris, yang bersifat kualitatif dengan cara/metode kajian deskritif analisis melalui bahan-bahan kepustakaan dan penelitian lapangan, ${ }^{7}$ yang berupa wawancara dengan sejumlah perusahaan yang memanfaatkan modal ventura.

Sebagai titik tolaknya akan digunakan studi kepustakaan di bidang hukum dan di bidang ekonomi mengenai timbulnya maupun perkembangan modal ventura di Indonesia dan luar negeri, sehingga dapat diambil kesimpulan mengenai hal-hal apa yang masih diperlukan untuk pengembangan modal ventura di Indonesia.
Metode yang dipergunakan dalam penulisan ini adalah yuridis normatif dengan teknik penelusuran bahan hukum melalui studi kepustakaan (library research), terutama studi terhadap bahan-bahan hukum yang berupa peraturan perundang-undangan dan perjanjian- perjanjian, ${ }^{8}$ buku-buku literatur, karya ilmiah yang ditulis oleh para ahli, hasilhasil penelitian dan laporan-laporan, majalah, surat kabar serta tulisan-tulisan lainnya.

\section{Pembahasan}

A. Faktor-faktor yang Mendorong Timbulnya Modal Ventura dan Mekanisme Kegiatannya

\section{Dasar hukum keberadaan modal ventura di Indonesia}

Keberadaan modal ventura sebagai salah satu bentuk lembaga pembiayaan di Indonesia yang diatur oleh Keputusan Presiden No. 61 Tahun 1988 dan Keputusan Menteri Keuangan No. 1252/KMK.013/1988 diharapkan dapat melakukan pembiayaan kepada perusahaan kecil dan menengah di Indonesia, sehingga terjadi keseimbangan kesempatan memperoleh modal bagi segala tingkatan usaha, dan masih banyak lagi ketentuan yang terkait, sebab "modal ventura (venture capital), yang mulai berkembang di Indonesia dan mulai berperan dalam perkembangan dunia

6 Moenadi, Ketidak Adilan Ekonomi dan Pemberantasan Hama Penyakit Ekonomi, (Malang: Badiya, tanpa tahun), hlm. 11.

7 Soetandyo Wignyosubroto, Hukum dan Metode-metode Kajiannya, Himpunan Bahan Penataran Latihan Tenaga Teknis Peneliti Hukum, (Jakarta: BPHN, 1982), hlm. 241.

8 Surjono Sukanto, Penelitian Hukum Normatif, (Jakarta: Adika Cipta, 1988), hlm. 184. 
usaha ini, pelaksanaannya adalah sebagai mitra kerja dan mitra usaha bagi perusahaan yang dibiayainya", dan hubungan kerjanya berupa hubungan hukum yang berdasarkan perjanjian.

\section{Pengertian modal ventura (venture capital) dan kegiatannya yang berisiko tinggi}

Menurut rumusan istilah bahasa, "Venture Capital (money) is invested or available for investment in stocks, especially funds is invested of never unseasened enterprise, called also equity capital or risk capital'. Perusahaan modal ventura adalah badan usaha yang melakukan usaha pembiayaan dalam bentuk penyertaan modal ke dalam suatu perusahaan yang menerima bantuan pembiayaan (investee corporation) untuk jangka waktu tertentu. Berdasarkan rumusan tersebut, maka dapat ditarik pengertian, bahwa modal ventura adalah modal/dana pembiayaan yang berbentuk penyertaan modal (equity) ke dalam suatu perusahaan dengan batasan jangka waktu tertentu.perusahaan modal ventura melakukan pembiayaan dengan disertai ikut mengelola perusahaan mitranya, agar perusahaan mitra yang dibiayainya dapat berkembang dan mendapatkan keuntungan sebagai salah satu upaya untuk mengurangi terjadinya risiko", ${ }^{10}$ sebab jika perusahaan mitra dapat keuntungan maka keuntungan pula bagi pemodal ventura, dan jika perusahaan mitra mengalami kerugian berarti kerugian pula yang diperoleh pemilik modal ventura.

\section{Karakteristik modal ventura}

Kegiatan modal ventura seharusnya mempunyai lima unsur, yaitu: sumber dana, kemampuan manajemen, lembaga yang mengawasi, likwiditas aktiva dan kesempatan usaha.Modal ventura berisiko tinggi maksudnya terletak pada tidak adanya jaminan, bahwa modal yang ditanamkan akan aman, juga tidak pasti akan mendapat keuntungan tinggi (capital gain).Model pembiayaan modal ventura tidak mempunyai perangkat hukum yang dapat memperkecil risiko, sekalipun untuk menanggung risiko kegagalan usaha. Bahkan apabila perusahaan pasangan usahanya pada saat tertentu memperoleh laba, maka belum tentu laba/ keuntungan itu dapat langsung menjadi deviden yang langsung dibagi kepada para pemegang saham.hukum pembiayaan modal ventura dilakukan dengan cara penyertaan modal, bukan cara pemberian kredit.

\section{Bentuk dan mekanisme pembiayaan modal ventura}

a. Bentuk Pembiayaan Modal Ventura

Pembiayaan yang dilakukan oleh perusahaan modal ventura terhadap perusahaan pasangan usahanya secara konsep

9 Webster's Third New Dictionary of the England Language Combridge, London, 1984, p. 2542, terjemahan bebas: Modal Ventura adalah uang yang diinvestasikan atau tersedia untuk investasi dalam bentuk saham, khususnya dana untuk perusahaan-perusahaan baru yang belum berpengalaman yang disebut juga dengan penyertaan modal atau modal berisiko.

10 Robbia Pancarasa, Mencari Bentuk Usaha Modal Ventura, (Harian Bisnis Indonesia, 4 September 1991), hlm. 6. 
berupa antara lain Pembiayaan penyertaan modal \{equity financing), Pembiayaan pinjaman (loan financing), Gabungan dari penyertaan modal dan pinjaman, Pembiayaan disertai jasa manajemen.

b. Tingkatan Pembiayaan Yang dilakukan Modal Ventura

Pembiayaan yang dilakukan modal ventura terhadap perusahaan pasangan usaha atau mitra bisnisnya sesuai dengan keadaan tahap pertumbuhan, dapat digolongkan ke dalam tingkatan-tingkatan, ${ }^{11}$ antara lain Pembiayaan tahap awal yang terdiri dari seed financing, start-up, first stage; Pembiayaan Ekspansi ${ }^{12}$ yang terdiri dari second stage, third stage, fourth stage; Akuisisi (Management Buyout Financing) yang terdiri pembiayaan akuisisi dan management buyout. ${ }^{13}$

Bagi setiap tingkatan pertumbuhan perusahaan tersebut tersedia juga alternatif pembiayaan lainnya (oportunity cost of capital) juga ${ }^{14}$ yang berbeda setiap tingkat. Jenis usaha juga menentukan aksesnya terhadap berbagai oentuk pembiayaan. Bahkan modal ventura hampir tidak pernah berdiri sendiri, oleh sebab itu harus selalu dirancang optimalisasi struktur pembiayaan yang memanfaatkan semua sumber dana yang ada.

c. Persamaan dan Perbedaan Modal Ventura dengan Bagi Hasil
1. Persamaan antara modal ventura dan bagi hasil lain

Praktek modal ventura model konsep Indonesia, yang berbentuk bagi hasil sebenarnya sudah terjadi pada masyarakat Indonesia.Contoh praktik modal ventura misalnya"Di desa, bahwa pemilik tanah yang sekaligus sebagai financial investor menyerahkan tanahnya untuk digarap serta memberi dana untuk pembelian bibit dan pupuk kepada seorang atau sekelompok petani penggarap agar menanam tanaman tertentu yang marketable, yang hasil atau keuntungannya dibagi berdasarkan kesepakatan" ${ }^{15}$ Mereka sama-sama menikmati hasil sesuai kontribusi orestasi masing-masing secara sepadan atau proporsional.Kenyataan tersebut menunjukkan bahwa pola kerja bisnis ventura, khususnya yang berbentuk bagi-hasil sudah terjadi secara informal dalam tatanan kehidupan masyarakat Indonesia.Oleh karena itu di Indonesia justru diutamakan penggunaan modal ventura untuk membiayai perusahaan menengah dan kecil, karena pola dasarnya (bagi hasil) sudah terjadi dikenal di Indonesia.

2. Perbedaan modal ventura dan bagi hasil yang lain

Meskipun pola dasar (bagi hasil) sudah dikenal di Indonesia, namun ada beberapa

11 NASBIC (National Association of Small Business Investment Companies), Layman's Guide to The Legal Aspects of Venture Investments, (Washington: Nasbic, 1987), p. 62.

$12 \mathrm{Ibid}$.

13 NASBIC, 1987, op.cit., p. 62.

14 Ibid.

15 Handowo Dipo, Sukses Memperoleh Dana Usaha; Dengan Tinjauan Khusus Modal Ventura, (Jakarta: Temprint, 1993), hlm. 36. 
perbedaan antara pola bagi hasil yang selama ini sudah ada di masyarakat Indonesia dengan model bagi hasil yang diterapkan oleh modal ventura. Perbedaan yang pokok terletak pada batas jangka waktu pembiayaan, ${ }^{16}$ Pola bagi hasil yang ada dan berkembang di masyarakat Indonesia selama ini tidak menentukan batas waktunya sampai kapan atau sampai berapa lama perjanjian atau kewajiban itu harus dilunasi, bahkan perjanjian bagi hasil di masyarakat Indonesia, terutama di daerah pedesaan, yang bergerak di bidang pertanian bentuk perjanjiannya umumnya dilakukan secara lisan atau tidak tertulis.

\section{Faktor-faktor yang mendorong keberadaan modal venturadi Indonesia}

Guna meningkatkan pembangunan ekonomi, modal ventura dapat merangsang pertumbuhan dan pengembangan usaha menengah dan kecil. Jika dibandingkan dengan kegiatan bank, undang-undang perbankan mensyaratkan adanya jaminan (agunan) untuk memperoleh pinjaman. Bunga pinjaman yang tinggi juga merupakan hambatan bagi pengusaha untuk mengambil pinjaman dari bank guna memulai atau mengembangkan usahanya. Akibatnya investasi lebih banyak terjadi dalam skala sangat kecil atau sebaliknya berskala besar sekali. Pembiayaan dari leasing (sewa guna usaha) masih mengemban risiko kegagalan, yang bebannya lebih banyak ditanggung oleh pihak lessee (pihak penerima investasi), sehingga daya tarik pembiayaan leasing lebih terpusat pada pembiayaan jangka pendek di sektor jasa dan industri kecil. Berdasarkan kondisi tersebut, maka perlu suatu alternatif pembiayaan yang berbentuk equity, sehingga mampu mengatasi kekurangan equity dari pengusaha atau wiraswasta dan mengurangi beban bagi perusahaan yang dibiayai sebab turut menanggung risiko bagi perusahaan yang belum mampu atau mapan menurut ukuran pembiayaan konvensional perbankan. Kondisi ini membutuhkan kehadiran modal ventura.

\section{Perbandingan dengan kegiatan modal ventura di negara lain}

a. Arah pembiayaan modal ventura di Indonesia

1. Modal ventura sebagai investasi untuk perusahaan

Semua pihak dari seluruh lapisan masyarakat dapat ikut serta dan merasakan pembangunan ekonomi nasional, maka diperlukan adanya kesempatan bagi perusahaan sekala kecil dan menengah untuk mengembangkanusahanyadengankesempatan untuk memperoleh modal sebagai sarana pembiayaan untuk menumbuh kembangkan kegiatan usahanya.Keluhan-keluhan klasik bagi setiap perusahaan-perusahaan kecil dan menengah adalah tidak ada atau kekurangan modal. "Perusahaan-perusahan kecil dan menengah ada kecenderungan menggunakan 
dana sendiri bagi modal (equity) kegiatan usahanya. Apabila perusahaan-perusahaan kecil dan menengah mencari pinjaman, maka jenis pinjamannya tergantung pada apakah pinjaman itu untuk investasi awal atau perluasan". ${ }^{17}$

Untuk investasi awal, perusahaan kecil dan menengah umumnya mengambil pinjaman-pinjaman jangka panjang dari saudara atau teman, sebab lebih mudah untuk mendapatkan uangnya, meskipun pengembaliannya mungkin mahal. Lembagalembaga keuangan merupakan alternatif yang terakhir. Sedangkan untuk pinjamanpinjaman jangka pendek, biasanya meminjam dari lembaga-lembaga keuangan dan dari sektor informal. Semula, bantuan permodalan untuk pengembangan perusahaan kecil dan menengah diupayakan berupa kemudahan memperoleh kredit.Para pengusaha kecil tersebut mengaku kesulitan bila menghadapi lembaga resmi karena menurut lembaga resmi tidak perlu meminjami perusahaan kecil, dengan alasan bahwa perusahaannya sudah berjalan dengan baik tanpa hutang, dan mereka khawatir jikaperusahaan kecil tidak mampu membayar hutang. ${ }^{18}$

Pemerintah telah berusaha membantu perusahaan kecil dan menengah melalui Lembaga Keuangan dan dengan mendirikan berbagai lembaga Pembiayaan Pembangunan atau koperasi-koperasi yang bertujuan mengembangkan perusahaan kecil dan menengah.Pemerintah dapat menganjurkan kepada Lembaga Keuangan untuk pembantu perusahaan kecil dan menengah melalui, ${ }^{19}$ menentukan pedoman atau persyaratan, bahwa Lembaga Keuangan memberikan pinjaman kepada perusahaan kecil dan menengah sejumlah proporsi tertentu dari portofolionya berdasarkan syarat-syarat tertentu yang mungkin lebih lunak;memberikan kerangka pola jaminan kredit untuk membantu menanggung risiko; memberikan subsidi bunga.

2. Profil sektor usaha kecil

Penelitian sebelumnya menunjukkan beberapa profil umum dari usaha kecil diIndonesia, yang sebetulnya tidak banyak berbeda dengan profil usaha kecil di Amerika Serikat atau negara lain. Sektor usaha kecil di Indonesia memiliki karakteristik sebagai yaitu antara lain Hampir setengahnya dari perusahaan kecil hanya mempergunakan kapasitas terpasang 60\% atau kurang; Lebih dari setengah perusahaan kecil didirikan sebagai pengembangan dari usaha kecilkecilan; Masalah utama yang dihadapi berbeda menurut tahap pengembangan usaha yaiu pada masa persiapan (sebelum investasi) terdapat dua masalah yang menonjol, yaitu permodalan dan kemudahan usaha (lokasi dan perijinan)

17 Kenneth James dkk, Aspek-aspek Finansial Usaha Kecil dan Menengah: Studi di Asean, (Jakarta: LP3ES, 1992), hlm. 9. 
sedang pada tahap selanjutnya (pengenalan usaha) adalah masalah pemasaran ditambah dengan masalah permodalan dan hubungan usaha; umumnya sukar untuk meningkatkan pangsa pasar; Tingkat ketergantungan terhadap bantuan dari pemerintah berupa permodalan, pemasaran dan pengadaan barang/bahan relatif tinggi; Hampir $60 \%$ dari usaha kecil masih mempergunakan teknologi yang tradisional; Hampir 70\% dari usaha kecil melakukan pemasaran langsung kepada konsumen; Sebagian besar pengusaha kecil untuk memperoleh bantuan perbankan merasa terlalu rumit dan dokumen vang harus dipersiapkan sulit dipenuhi.

Keadaan di Indonesia, terutama di kotakota besar telah bangkit generasi pengusaha baru, baik perusahaan besar maupun kecil. Sepintas pandang hal ini sangat melegakan dan memberi harapan, tetapi jika diteliti benar perkembangan dan pertumbuhan dunia usaha di Indonesia, terutama perusahaan yang dikelola keluarga, baik sekala besar, menengah maupun kecil umumnya tidak bertahan lama, bahkan jarang yang sampai berhasil sampai generasi kedua. ${ }^{20}$ Adanya beberapa perusahaan besar saat ini pada awalnya dimulai dengan usaha kecil-kecilan.Tidak dapat dipungkiri, bahwa perusahaan kecil dengan segala kelemahannya adalah salah satu sendi kehidupan ekonomi Indonesiasebab Perusahaan kecil menyediakan lapangan kerja untuk berjutajuta rakyat Indonesia; Perusahaan kecil ikut membayar pajak; Perusahaan kecil merupakan ujung tombak industri nasional; Perusahaan kecil menjadi pedagang perantara dan pengumpul hasil panen pertanian; Perusahaan kecil memproduksi banyak sektor kebutuhan pokok rakyat banyak. ${ }^{21}$

3. Peraturan-peraturan dan kebijakan bagi Investasi untuk Perusahaan Kecil

Perhatian Pemerintah Indonesia terhadap pengusaha kecil dan menengah nasional sebenarnya sudah dilakukan sejak lama. Tahun 1973 pemerintah membentuk Asuransi Kredit Indonesia (Askrindo) dan Bahana Pembinaan Usaha Indonesia (Bahana PUI). ${ }^{22}$ Asuransi Kredit Indonesia (Askrindo) bertugas memberi fasilitas asuransi kredit bagi pengusaha kecil nasional agar mereka dapat mendapat fasilitas kredit investasi kecil ataupun kredit modal kerja permanen. Bahana Pembinaan Usaha Indonesia (Persero) didirikan sebagai lembaga keuangan pemerintah yang mengkhususkan diri untuk membiayai usaha kecil dan menengah, khususnya berupa penyertaan modal saham. ${ }^{23}$ Keberadaan perusahaan modal ventura beserta kegiatannya di Indonesia diharapkan dapat berperan untuk mengembangkan perusahaan

20 Narbun, B.N., Kekuatan \& Kelemahan Perusahaan Kecil, (Jakarta: Pustaka Binaman Pressindo, 1993), hlm. 2.

21 Ibid.

22 Bahauddin Darus, Venture Capital Investment, Indonesian Experience,Writing tobe presented on the Occacion of IIB-NDFIs 13 annual meeting in Tripoli on 14 Sha'ban 1412 H, 17 Februari 1992.

23 Ibid. 
pasangan usahanya, terutama perusahaanperusahaan kecil dan menengah. ${ }^{24}$ Inilah kekhususan kinerja modal ventura yang ada di Indonesia.Memang ada pihak-pihak tertentu yang menyatakan, bahwa konsep modal ventura untuk membiayai perusahaan kecil dan menengah yang diterapkan di Indonesia kurang tepat jika dibandingkan dengan konsep venture capital di negara-negara lain, akan tetapi bagi Indonesia tentunya boleh juga menerapkan konsep yang berbeda.

b. Modal Ventura di Negara lain

Peranan modal ventura di negaranegara asia pasifik menumbuhkan dan mengembangkan scince park atau industrial park atau technology park (taman Ilmu, taman industri, taman teknologi). Pembiayaan yang dilakukan modal ventura mempunyai sasaran yang bermacam-macam, pembiayaan untuk komputer baik perangkat keras maupun lunak, mikro elektronik, automasi, instrumentasi, peralatan elektronik, kedokteran, farmasi, juga menyangkut penelitian obat dan penyakit. ${ }^{25}$

1. Modal ventura di Amerika

Modal Ventura di Amerika umumnya mulai membiayai perusahaan pasangan usaha pada tahap start-up corporation dan keluar dari perusahaan pasangan usaha pada saat go public, di sinilah letak bahwa modal ventura mempunyai peran penting untuk meningkatkan kegiatan pasar modal.Modal ventura di Amerika umumnya membiayai bisnis-bisnis baru, yang sebenarnya agak berisiko, tetapibisnis tersebutbisa berkembang dan capital marketable dan dianggap sebagai future bisnis, ${ }^{26}$ sehingga justru merupakan kesempatan bagi modal ventura untuk mendapatkan keuntungan.Di Amerika Serikat modal ventura (venture capital) pada umumnya membiayai perusahaan yang bergerak di bidang teknologi tinggi (high tecnology) yang membutuhkan dana besar, sedangkan pengusaha yang bersangkutan tidak mempunyai modal yang mencukupi. Maka pembiayaan dilakukan dengan modal ventura, dengan harapan setelah berdiri perusahaan tersebut berkembang dengan cepat (quick yielding), sehingga modal (ventura) yang berisiko tinggi tersebut dalam waktu singkat akan kembali, bahkan mendapatkan keuntungan dari penjualan sahamnya (capital gain) dengan keuntungan yang besar pula, akibat harga sahamnya naik berlipat ganda. ${ }^{27}$

2. Jepang

Kegiatan modal ventura di Jepang arahnya adalah untuk membiayai perusahaan besar yang akan berdiri tetapi masih kekurangan modal, dengan harapan perusahaan yang sudah besar tersebut akan berkegiatan di bidang usaha yang lebih besar lagi, sehingga harapannya juga akan berkembang dengan cepat dan memperoleh keuntungan yang cepat pula. ${ }^{28}$

24 Soebiyakto, Modal Ventura Sebagai Alternatif Pembiayaan Usaha Kecil, Laporan Akhir Tim Pengkajian, (Jakarta: Badan Pembinaan Hukum Nasional, Departemen Kehakiman, T, 1994), hlm. 41.

25 Robert Kay Guan Chia \& Kwei Cheong Wong, Venture Capital in The Asia Pasific Region: with Special Reference to Singapore, (Singapore: Toppan Co (S) Ltd, 1989), p. 12.

26 Ibid.

27 Ibid.

28 Handowo Dipo, 1993, op.cit. hlm. 9. 


\section{Taiwan}

Awal tahun 1988 di Taiwan telah memiliki taman teknologi model seperti Silycon Valley, yang telah memiliki 73 (tujuh puluh tiga) perusahaan pembiayaan modal ventura. Pada tahun 1990 taman teknologi tinggi tersebut berjumlahlebihdari200(duaratus)perusahaan, dengan tenaga kerja lebih dari 80.000 (delapan puluh ribu) orang, yang diharapkan pada tahun 1997 memiliki perputaran dana sekitar US\$9 (sembilan) milyar, padahal di tahun 1987 baru mengedarkan dana sebesar US\$ 850 juta. ${ }^{29}$ Salah satu taman Imu milik Taiwan yang berhasil baik dikarenakan pembiayaan dari modal ventura adalah taman ilmu Hsincu/ HSIP (Hsincu Science-based Industrial Park). Taiwan juga berusaha memajukan industri pemintalan yang berteknologi tinggi dengan cara pengembangan kawasan pengolahan ekspori Contohnya Kaoshiung, Nantze, dan Taichung. Kesuksesan taman Imu yang dimiliki oleh Taiwan tersebut, yang didukung oleh 10 (sepuluh) lembaga modal ventura ternyata mencapai keberhasilan yang sangat mengagumkan dan merupakan inspirasi yang mendorong negara-negara tetangganya di Asia Pasifik untuk meniru kemajuan yang diperoleh Taiwan tersebut. ${ }^{30}$

4. Korea Selatan

Korea Selatan mengawali kegiatan usaha modal ventura dengan bedirinya perusahaan modal ventura yang pertama: yaitu Korea Technology Advanced Corporation (K-TAC), yang bertujuan mengkomersialkan hasil-hasil penelitian dan pengembangan ilmu dari Institut Ilmu dan Teknologi Korea. ${ }^{31}$ Pada tahun 1984 lebih dari 20,5 milyar won, telah disediakan dana bagi pengembangan perusahaan modal ventura di Korea, yang sekarang Korea merupakan salah satu negara macan Asia di bidang perkembangan ekonominya. ${ }^{32}$

5. Singapura

Di Singapura tersebut keberhasilan pengembangan ilmu dan teknologi yang melibatkan peran modal ventura, namun juga tidak lepas dari peran serta badanbadan atau lembaga-lembaga pemerintah, seperti Komisi Pembangunan Ekonomi (Economie Development Boarcf) dan Dewan Ilmu Singapura (The Singapore Science Council), yang bertanggung jawab untuk mempromosikan dan mengurus administrasi taman ilmu tersebut.Peranan pemerintah Singapura untuk pengembangan modal ventura juga dibuktikan dengan cara/melalui badan Komisi Pembangunan Ekonomi milik pemerintah Singapura, yang memanifestasikan dana untuk modal ventura melalui dua cara pendekatan, yaitu Investasi langsung bagi pendanaan dan proyek-proyek modal ventura dan Kerja sama investasi dengan perusahaanperusahaan lokal bagi pendanaan dan proyekproyek modal ventura.

29 Christopher C. Golis, Enterprise and Venture Capital: A Business Builders and Investors Handbook,(Australia: Allen \& Unwin Pty Ltd, 1993), p. 146.

30 Robert Kay Guan Chia \& Kwei Cheong Wong, 1989, op.cit., pp. 150-151.

31 Robert Kay Guan, 1989, op.cit., pp. 150-151.

32 Ibid. 


\section{Kanada}

Di Kanada, modal ventura banyak diarahkan untuk membiayai perusahaan kecil dan menengah.

In the early 1980s, high unemployment and the rapid exodus of capital from Quebec led the province to offer seed capital and tax incentive for a new kind of venture capital fund that provided equity to small and medium-sized businesss.The Canadian venture capital experiment, at a minimum, will provide valuable lessons about how a country's small and mediumsized businesses benefit when their venture capital comes primarily from union-controlled funds. At a maximum, the Canadian experiment will teach Americans how to tap into household assets to build equity investments that marry social and economic ends. ${ }^{33}$

Bagi Indonesia keadaannya sangat berbeda, latar belakang sosial ekonomi juga berbeda, bahkan falsafah hidup dan ideologi kehidupan juga berbeda, sehingga sangatlah wajar jika gerak kegiatan usahanya juga berbeda. Kenyataannya memang kegiatan modal ventura di Indonesia tidak mengikuti konsep modal ventura di negara-negara asia pasifk. Oleh karena tujuan utamanya di Indonesia bukanlah membiayai perusahaan yang berteknologi tinggi, tetapi justru bertujuan untuk membiayai perusahaan kecil dan menengah yang biasanya tidak diminati oleh investasi asing.Kegiatan modal ventura di Indonesia tampaknya memang memiliki misi khusus, yang agak berbeda dengan konsep Amerika. Misi khusus ini adalah untuk membiayai perusahaan kecil dan menengah dengan harapan perusahaan-perusahaan kecil yang mendapat sentuhan modal ventura tersebut berkembang dengan baik, sehingga di negeri ini harapannya terjadi keseimbangan perkembangan dan pertumbuhan dunia usaha baik dari usaha sekala besar, menengah maupun kecil. Kegiatan modal ventura di Indonesia ini tampaknya misinya mirip dengan misi modal ventura di Kanada.

Di Negara Indonesia, prinsip umumnya adalah bahwa perusahaan modal ventura menghendaki perusahaan pasangan usahanya dapat berkembang dengan baik, sebab keuntungan perusahaan modal ventura tergantung pada keberhasilan dari perusahaan yang dibiayainya.Jika perusahaan pasangan usaha (PPU) berhasil tumbuh, berkembang dan memperoleh keuntungan, maka perusahaan modal ventura juga memperoleh keuntungan, yang berupa dividen dan juga nilai sahamnya menjadi naik (capital gain). Tetapi sebaliknya jika perusahaan pasangan usaha mengalami kegagalan, maka perusahaan modal ventura juga ikut mengalami kerugian, dan bahkan boleh jadi nilai sahamnya menurun (capital loss).

c. Kegiatan perusahaan modal ventura di Indonesia

Sampai saat ini jika dibandingkan jumlah perusahaan kecil yang ada di Indonesia dengan jumlah perusahaan kecil yang telah 
dibiayai oleh modal ventura masih jauh perbandingannya dan masih baru sebagian kecil saja perusahaan kecil yang memperoleh pembiayaan dari modal ventura.Menurut data Biro Pusat Statistik (BPS) hingga tahun 1998 jumlah usaha kecil dan menengah (UKM) yang terdiri dari Industri Kecil berdasarkan Undang-undang Nomor 9 Tahun 1995, sebanyak 2.104.856 unit usaha, sedangkan jumlah Dagang Kecil sebanyak 8.325.351 unit, yang tersebar di berbagai daerah. ${ }^{34}$ Berdasarkan data dari Departemen Keuangan bagian modal ventura, setiap propinsi telah didirikan perusahaan modal ventura yang dirintis oleh pemerintah. Perusahaan Modal Ventura yang sekarang ada di Indonesia berjumlah 29 perusahaan. Setiap perusahaan modal ventura dalam jangka waktu 3 (tiga) sampai 5 (lima) tahun dapat membiayai perusahaan pasangan usaha lebih kurang 80 perusahaan, sehingga harapannya sedikit demi sedikit kegiatan modal ventura ini dapat melakukan pembiayaan kepada perusahan kecil dan menengah yang jumlahnya sangat banyak sebagaimana tersebut di atas secara lebih meluas.

Di indonesia didirikan perusahaanperusahaan yang mempunyai misi khusus untuk membantu pengusaha kecil dan menengah nasional, tanpa semata-mata tergantung pada target keuntungan, tetapi juga tetap memperhatikan aspek pengembangan nasional yang lebih luas yaitu diantaranya PT.
Bahana Pembinaan Usaha Indonesia (Persero) dan PT. Sarana Jatim Ventura yang wilayah operasionalnya di Jawa Timur, PT Sarana Jabar Ventura yang wilayah operasionalnya di Jawa Barat.

4. Prospek modal ventura di Indonesia

Masa depan (prospek) modal ventura serta pertumbuhannya bagi setiap negara sangat dipengaruhi oleh berbagai faktor di masingmasing negara yang bersangkutan. Faktorfaktor tersebut meliputi Prospek jangka menengah kegiatan ekonomi dan bisnis di negara yang bersangkutan, Minat investasi para pemilik modal, Tingkat pemberian balas jasa modal yang berlaku di pasaran, Semangat berusaha bagi semua kalangan, baik perusahaan sekala kecil, menengah maupun perusahaan besar dan Perlindungan hak milik intelektual (HaKI), dan perkembangan kegiatan pasar modal.Semakin cerah masa depan ekonomi suatu negara, maka para investor modal ventura (venture capitalist) akan semakin bergairah pula untuk terjun di bidang usaha modal ventura ini.

Sebenarnya lingkungan ekonomi Indonesia sangat mengundang perlunya pengembangan modal ventura. Diversifikasi kegiatan usaha yang beraneka ragam (antara lain di bidang agrobisnis), pasar yang terbuka lebar untuk semua jenis produk baik pasar dalam negeri maupun untuk ekspor non-migas, tersedianya tenaga kerja yang banyak, sehingga menggugah untuk membuka lahan- 
lahan kegiatan usaha baru, yang sekaligus merupakan tempat subur tumbuhnya kegiatan modal ventura.

Salah satu usaha untuk mengembangkan kegiatanmodalventuradiIndonesia diprakarsai oleh UNDP. Salah satu bentuk prakarsa UNDP adalah usaha pembinaan industri kecil dan menengah, seperti Fortifiying Fund. Jika kegiatan ini berhasil, maka mekanisme semacam ini akan dimanfaatkan dan dijadikan contoh oleh paling tidak 42 (empat puluh dua) negara berkembang lainnya yang menjadi anggota Perserikatan Bangsa Bangsa (PBB). Keistimewaan Fund tersebut adalah adanya bantuan teknis dari UNDP melalui UNISTAR (Short Term Advisory Resources) untuk memperoleh ahli-ahli yang akan diberikan guna membantu pengembangan perusahaanperusahaan kecil dan menengah tersebut.

\section{B. Beberapa Masalah Hukum Modal Ventura}

\section{Modal ventura sebagai investasi (penyertaan modal)}

Lembaga pembiayaan termasuk modal ventura dalam rangka menjalankan usahanya dilarang melakukan penarikan dana secara langsung dari masyarakat dalam bentuk giro, tabungan, deposito, penerbitan surat sanggup bayar (promissory note), maka dana yang diperoleh perusahaan modal ventura sangat terbatas, yakni antara lain Dana investasi dari penyertaan modal atau penjualan saham dari perusahaan modal ventura itu sendiri dan laba/keuntungan serta Dana yang diperoleh dari pinjaman. Terbatasnya sumber dana yang dapat diperoleh oleh perusahaan modal ventura akan mengakibatkan dana yang dimiliki menjadi sangat terbatas, sehingga hal ini menjadi hambatan dan terbatas pula untuk membiayai perusahaan-perusahaan pasangan usaha, yang berupa perusahaan kecil dan menengah.

Apabila ekonomi secara makro mengalami ketidakstabilan, maka perkembangan dunia usaha termasuk pembiayaan perusahaan dengan sistem penyertaan modal sebagaimana yangdilakukanmodalventurajugamenghadapi berbagai kendala, terutama selama bunga bank tinggi, maka pembiayaan dengan sistem investasi penyertaan modal pasti mengalami kemunduran. Apabila bunga bank tinggi, orang lebih suka menginvestasikan uangnya ke dalam bank dalam bentuk deposito atau tabungan yang secara pasti setiap bulan atau bahkan harian mendapatkan bunga yang cukup tinggi.Sehingga perusahaan modal ventura akan mengalami kesulitan untuk memperoleh dana, dengan demikian kegiatan pembiayaan penyertaan modal yang dilakukan oleh perusahaan modal ventura menjadi sangat terbatas. Sesungguhnya tingginya bunga kredit atau bunga pinjaman ini sangat mempengaruhi pertumbuhan dan perkembangan perusahaanperusahaan pada umumnya. Bunga kredit semakin tinggi, maka bagi dunia usaha semakin mengalami kesulitan untuk mengembangkan perusahaannya. Tampaknya meskipun bunga bank merupakan bunga konvensional atau bunga yang ditentukan 
berdasarkan perjanjian, tetapi jika dibiarkan akan terjadi perubahan-perubahan yang tidak stabil, bahkan bisa menjadi sangat tinggi, oleh karena itu menurut hemat penulis perlu adanya pengendalian, sehingga bunga kredit tidak terlalu tinggi dan stabilitas perekonomian juga relatif terjamin. Pengendalian ini dapat dilakukan dengan suatu keputusan kebijakan atau dengan peraturan perundang-undangan yang mengatur tentang bunga paling tinggi, yang tidak boleh dilampaui.

\section{Modal ventura sebagai instrumen pembiayaan perkreditan}

Menurut Keputusan Presiden No. 61 Tahun 1988, bahwa pembiayaan yang dilakukan modal ventura dengan cara penyertaan modal. Berdasarkan konsep yang dikemukakan oleh Clinton Ricardson, bahwa modal ventura dapat menyertakan modalnya dengan membeli langsung saham dari perusahaan yang dibiayai, dengan pinjaman atau gabungan dari keduanya. ${ }^{35}$ Kalau pembiayaan dilakukan dengan cara pinjaman (loan) berarti pembiayaan modal ventura dapat dilakukan berbentuk kredit. Di dalam praktik di Indonesia ternyata memang terjadi pembiyaan dengan pinjaman, meskipun seharusnya tidak sekedar pinjaman semata, melainkan sebagai pelengkap dari penyertaan modal, tetapi ternyata ada yang pembiayaannya berupa pinjaman belaka.

\section{Modal ventura sebagai bentuk usaha dan aspek hukum yang mendasarinya}

Modal ventura sebagai kegiatan usaha, maka tentunya tinjauannya mengenai hukum perusahaan, oleh karena itu pembahahasannya adalah menyangkut bentuk badan usaha. Pasal 3 ayat (2) Keputusan Presidan Republik Indonesia No. 61 tahun 1988 juncto pasal 9 ayat (2) SK Menteri Keuangan RI No.1251/ KMK.013/1988 menyebutkan, bahwa perusahaan modal ventura harus berbentuk Perseroan Terbatas atau Koperasi.

Terjadinya kesepakatan untuk dituangkan ke dalam perjanjian pem-biayaan antara perusahaan modal ventura (PMV) dengan perusahaan pasangan usahanya (PPU) ternyata diawali pula dengan suatu konsep perjanjian dari pihak perusahaan modal ventura atau investor (venture capitalist), yang biasa disebut dengan perjanjian baku (standard contract).Perjanjian baku dialihbahasakan dari istilah yang dikenal di dalam bahasa Inggris "standard contract', atau di dalam bahasa Belanda "standaard voorwaarden" atau "algemene voorwaarden". "Baku" artinya patokan, ukuran, acuan, yang memiliki arti tetap yang dapat menjadi pegangan umum, sehingga perjanjian baku mengandung arti suatu perjanjian yang sudah ditetapkan patokannya atau ukurannya. $^{36}$ Secara

35 Clinton Richardson, The Venture Capital: Complete Guide To Venture Capital, (New York: A. Plume, 1987), p.32.

36 Mariam Darus Badrulzaman, Aneka Hukum Bisnis, (Bandung: Alumni, 1994), hlm. 46. 
tradisional suatu perjanjian dianggap terjadi berlandaskan asas kebebasan berkontrak di antara dua pihak yang mempunyai kedudukan yang seimbang dan kedua belah pihak berusaha untuk mencapai kesepakatan yang diperlukan bagi terjadinya perjanjian tersebut melalui proses negosiasi tawar-menawar di antara produsen dan konsumen.Kemungkinan yang diberikan hanyalah memilih salah satu alternatif yang disediakan oleh produsen. Syarat-syarat yang disodorkan oleh produsen, yang berupa klausul- klausul yang dinilai memberatkan konsumen, yang banyak muncul di dalam perjanjian-perjanjian baku yang disebut klausul eksonerasi (dalam bahasa Belanda: exoneratie clausule) atau klausul eksemsi (dalam bahasa Inggris: exemption clause)."Di dalam pustaka-pustaka hukum Inggris", ${ }^{37}$ klausul eksonerasi disebut klausul eksemsi (exemption clause)atau (exclusion clause),bahkan juga ada yang memberi padanan kata dengan (exception clause)."Di dalam pustaka-pustaka hukum Amerika Serikat klausul itu disebut exculpatory clause, warranty disclaimer clause, dan limitation of liability clause". ${ }^{38}$

Menurut Mariam Darus Badrulzaman pengertian klausul eksonerasi/ eksemsi adalah klausul yang berisi pembatasan tanggung jawab dari produsen atau pemberi jasa atau pemberi kredit (kreditur).Sebelum terjadi kesepakatan antara kedua belah pihak, yakni antara perusahaan modal ventura sebagai calon investor (venture capitalist) dengan perusahaan pasangan usaha sebagai calon penerima investasi (investee corporation) terjadi suatu perundingan atau negosiasi untuk mencapai kesepakatan yang dilukiskan sebagai persyaratan kehendak yang disetujui (overeenstemmende wilsverklaring) antar para pihak. ${ }^{39}$

\section{Perjanjian Hukum diantara Pelaku Modal Ventura}

Pada saat ini di Indonesia, hubungan hukum perusahaan modal ventura dengan pasangan usahanya termasuk hubungan hukum yang lain, yang menggunakan perjanjian baku belum ada yang membatasi, kecuali klausula baku di dalam hubungan hukum perusahaan dengan konsumen barang dan jasa yang dimuat di dalam Undang-undang Nomor 8 Tahun 1999 tentang Perlindungan Konsumen. Apabila ada perjanjianperjanjian yang berat sebelah sebagai akibat tidak atau kurang bekerjanya mekanisme asas kebebasan berkontrak dan terjadinya perjanjian baku yang tidak seimbang, maka pemerintah harus meluruskan keadaan yang demikian itu. Dengan berpegangan pada sila "Keadilan sosial bagi seluruh rakyat Indonesia", maka demi keadilan kita harus melindungi pihak yang lemah. Perlindungan yang harus diberikan adalah untuk mencegah

37 Lihat Sutan Remy Sjahdeini, 1993, op.cit., hlm. 73, yang mengambil dari Mahesh M. Kumar, G.H. Treitel, 1987, op.cit., hlm. 73.

38 Sutan Remy Sjahdeini, 1993, op.cit., hlm. 73.

39 Bandingkan Mariam Darus Badrulzaman, 1994, op.cit., hlm. 24. 
kesewenang-wenangan dari pihak yang kuat agar keseimbangan dan keadilan dapat terpelihara.

Bagi Indonesia, berlakunya asas kebebasan berkontrak dalam hukum perjanjian antara lain dapat disimpulkan dari Pasal 1329 Kitab Undang- undang Hukum Perdata, yang menentukan bahwa setiap orang cakap untuk membuat perjanjian, kecuali jika ditentukan tidak cakap oleh undang-undang. Menurut Pasal 1332 Kitab Undang-undang Hukum Perdata dapat disimpulkan, bahwa asalkan menyangkut barang-barang yang bernilai ekonomis, maka setiap orang bebas untuk memperjanjikannya. Asas kebebasan berkontrak menurut hukum Indonesia meliputi ruang lingkup sebagai berikut: ${ }^{40}$ Kebebasan untuk membuat atau tidak membuat perjanjian, Kebebasan untuk memilih pihak dengan siapa ia ingin membuat perjanjian, Kebebasan untuk menentukan atau memilih causa dari perjanjian yang akan dibuatnya, Kebebasan untuk menentukan obyek perjanjian, Kebebasan untuk menentukan bentuk suatu perjanjian, Kebebasan untuk menerima atau menyimpangi ketentuan undang-undang yang bersifat pilihan atau opsional (anvullend, optional).

Ditinjau dari aspek hukum memang terjadinya perjanjian berdasarkan asas kebebasan berkontrak, oleh sebab itu agar mencapai rasa keadilan pada saat melakukan pembicaraan (negosiasi) guna mencapai kesepakatan, maka diperlukan kedudukan yang imbang atau sederajat antara para pihak.
Persoalannya calon perusahaan pasangan usaha merupakan pihak yang membutuhkan dana, sehingga seringkali harus mengikuti kehendak dari perusahaan modal ventura sebagai pihak yang akan memberi modal. Di lain pihak berhubung penyertaan dana dengan sistem modal ventura ini mengandung risiko tinggi bagi pemodal, maka dari awal pemodal (venture capitalist) harus berhati-hati guna menyelamatkan dana/modal yang dimasukkan ke dalam perusahaan mitra bisnisnya. Oleh sebab itu perlu adanya kepastian hukum tentang bentuk kerjasama maupun tanggung jawab dari masing-masing pihak.

Permasalahan tersebut disarankan indonesia perlu segera menentukan tentang aturan dasar perjanjian baku, yang pembentukannya dengan mempertimbangkan peraturan-peraturan dasar yang sudah ada, yakni: Ketentuan yang tercantum di dalam pasal 18 Undang-Undang No. 8 Tahun1999 tentang Perlindungan Konsumen, Pasal 6.5.2. dan 6.5.1.3. Burgelijke Wetboek di Belanda yang baru, aturan-aturan dasar yang telah ditetapkan oleh pengadilan-pengadilan di Inggris tentang Ketentuan Dokumen Baku, dan pasal 2-302 Uniform Code 1978 di Amerika Serikat. Agar keberadaan modal ventura mempunyai landasan yang lebih kuat dan cepat memasyarakat serta mendapat dukungan dari berbagai pihak, alangkah baiknya jika Keputusan Presiden No. 61 Tahun 1988 tentang Lembaga Pembiayaan ini diperbaiki dalam bentuk undang-undang. 
Pelaksanaan sistem pembiayaan modal ventura terdiri dua bentuk, yaitu pertama penyertaan modal dengan cara membeli saham (equity) kepada perusahaan pasangan usaha, yang keuntungan bagi pemodal diperoleh selain dividen juga nilai tambah harga jual saham yang dimiliki (capital gain) pada saat melepaskan diri dari perusahaan yang dibiayai (divestasi). Kedua memberi pinjaman berupa kredit dengan disertai bunga sesuai dengan bunga yang berlaku di bank. Hanya saja pemberian kredit tersebut tidak memerlukan jaminan, sebab pinjaman dari modal ventura diberikan beserta dana yang berbentuk saham. Kegiatan perusahaan modal ventura dirasakan sangat membantu bagi pengusaha kecil dan menengah di indonesia, sebah selain pembiayaannya tidak memerlukan barang jaminan (agunan) juga menempatkan orang (tenaga) sebagai komisaris, yang berfungsi mengawasi jalannya perusahaan dan sekaligus memberikan konsultasi manajemen perusahaan, terutama manajemen keuangan.

\section{Simpulan}

Reevaluasi modal ventura di Indonesia sebagai lembaga permodalan bagi dunia usaha yang ada di Indonesia dilakukan karena hanya dapat dimanfaatkan perusahaan- perusahaan besar, sehingga kehidupan usaha kecil dan menengah kurang mendapatkan kesempatan untuk memperoleh modal guna mengembangkan usaha, maka munculnya modal ventura diharapkan untuk memberi permodalan pada usaha kecil dan menengah. Dengan adanya Keputusan Presiden Nomor 61 Tahun 1988 dan Surat Keputusan Menteri Keuangan Nomor 1251/KMK.013/1988, dasar hukum keberadaan lembaga pembiayaan modal ventura sudah jelas, tetapi aturan kinerja modal ventura belum ada, sehingga di dalam praktek berlandaskan asas kebebasan berkontrak, yang pelaksanaannya berdasarkan perjanjian (kesepakatan) yang diserahkan kepada para pihak. Berhubung modal ventura ini mengemban risiko yang tinggi, maka perusahaan modal ventura perlu berhatihati untuk menyertakan modalnya kepada pasangan usaha, bahkan untuk mengurangi risiko, maka PMV menentukan syarat-syarat secara sepihak, sehingga terjadilah perjanjian baku. Perjanjian baku (Standard contract) jika tidak dilakukan pengawasan (kontrol) akan menimbulkan ketidakseimbangan, sehingga pihak kreditur akan cenderung menekan kepada pihak debitur, sedangkan pihak debitur sebagai pihak yang lemah biasanya karena kebutuhannya terpaksa menerima apa yang disyaratkan oleh kreditur. 


\section{DAFTAR PUSTAKA}

\section{Buku}

ASBIC (National Association of Small Business Investment Companies). Layman's Guide to The Legal Aspects of Venture Investments. Washington: Nasbic, 1987.

Badrulzaman, Mariam Darus. Aneka Hukum Bisnis. Bandung: Alumni, 1994.

B.N., Narbun. Kekuatan \& Kelemahan Perusahaan Kecil. Jakarta: Pustaka Binaman Pressindo, 1993.

Chia, Robert Kay Guan \& Kwei Cheong Wong.Venture Capital in The Asia Pasific Region: with Special Reference to Singapore. Singapore: Toppan Co.(S) Ltd, 1989.

Darus, Bahauddin. Venture Capital Investment, Indonesian Experience. Writing to be presented on the Occacion of IIB-NDFIs 13 annual meeting in Tripoli on 14 Sha'ban 1412 H. 17 Februari 1992.

Dipo, Handowo. Sukses Memperoleh Dana Usaha; Dengan Tinjauan Khusus Modal Ventura. Jakarta: Temprint, 1993.

Golis, Christopher C. Enterprise and Venture Capital: A Business Builders and Investors Handbook. Australia: Allen \&Unwin Pty Ltd, 1993.

James, Kenneth dkk. Aspek-aspek Finansial Usaha Kecil dan Menengah: Studi di Asean. Jakarta: LP3ES, 1992.
Moenadi. Ketidak Adilan Ekonomi dan Pemberantasan Hama Penyakit Ekonomi. Malang: Badiya, tanpa tahun. Rahardjo, Satjipto. Ilmu Hukum. Jakarta: Balai Pustaka, 1979.

Richardson, Clinton. The Venture Capital: Complete Guide To Venture Capital. New York: A. Plume, 1987.

Sitohang, Sonang. Perkembangan Usaha Kecil Menengah (UKM) Sebelum dan Sesudah Krisis Moneter serta Kebijaksanaan Pengembangannya di Indonesia. Surabaya: Program Pascasarjana, 2001.

Sjahrir. Persoalan Ekonomi Indonesia: Moneter. Perkreditan dan Neraca Pembayaran. Jakarta: Pustaka Sinar Harapan, 1995.

Soebiyakto. Modal Ventura Sebagai Alternatif Pembiayaan Usaha Kecil. Laporan

Akhir Tim Pengkajian. Jakarta:

Badan Pembinaan Hukum Nasional, Departemen Kehakiman, 1994.

Sunarjati Hartono. Politik Hukum Menuju Satu Sistem Hukum Nasional. Bandung: Alumni, 1991

Webster's Third New Dictionary of the England Language Combridge, London, 1984.

\section{Surat Kabar}

Pancarasa, Robbia. Mencari Bentuk Usaha Modal Ventura. Harian Bisnis Indonesia, 4 September 1991. 